\title{
Kesesuaian Pemenuhan Kebutuhan Difabel TunaNETra Dan Tunadaksa Di Kota Surakarta TERHADAP KRITERIA Kota RAMAH DIFABEL
}

\author{
YULI ALFIANI TAUDA ${ }^{1}$ \\ PROGRAM STUDI PERENCANAAN WILAYAH DAN KoTA \\ FAKULTAS TEKNIK \\ UNIVERSITAS SEBELAS MARET, SURAKARTA \\ email: yulialfianita@gmail.com \\ SOEDWIWAHJONO ${ }^{2}$ \\ PROGRAM STUdI PERENCANAAN WILAYAH DAN KoTA \\ FAKULTAS TEKNIK \\ UnIVERSiTAS SEBELAS MARET, SURAKARTA \\ RUfia Andisetyana PUTRI ${ }^{3}$ \\ PROGRAM STUdi PERENCANAAN WILAYAH DAN KotA \\ FAKULTAS TEKNIK \\ UnIVERSITAS SEBELAS MARET, SURAKARTA
}

\begin{abstract}
:
The city of Surakarta is one of the cities in Indonesia which has become the center of disability rehabilitation. The rehabilitation center bring out Surakarta City as the top 15 nominees from 155 cities as a city with easy access to disable in the field of transportation. Good history and diverse appreciation should made Surakarta City to have provided all the needs of disability both on social services to the fulfillment of infrastructure facilities without exception. Therefore, the importance of researching the suitability of the needs of the tunanetra and the tunadaksa to the criteria of the distric-friendly city to be able to find out how big the level of the city of Surakarta in achieving the predicate according to the standard of the disability-friendly city. The research method used is the quantitative method. Researchers use scoring technique to determine the value and weight of each indicator criterion on each variable. There are 6 criteria that will be in the value of the criteria of public transport, rehabilitation, education, tool assistance, the role of development and employment. The result of the research shows that the city of Surakarta is classified as inappropriate, this means that city of Surakarta has not been able to accomodated the needs of the disabled. discrepancies caused by three criteria that have not met the standards, among others: accessibility criteria of public transport and employment entry in the classification is not appropriate, the role of development included in the less appropriate classification and criteria for rehabilitation, formal education and assistance tools included in the appropriate classification.
\end{abstract}

Keywords: Disability, Needs of disability, Disability-friendly city.

\section{PENDAHULUAN}

Kota merupakan salah satu tempat kehidupan manusia yang harusnya dapat memberikan pelayanan terhadap kebutuhan dasar manusia. Menurut CRPD (Convention on the right of person with disability) Semua kebutuhan manusia termasuk kebutuhan difabel harus terpenuhi guna mewujudkan kesetaraan pemenuhan kebutuhan. Berdasarkan Undang-Undang Negara Republik Indonesia Nomor 19 Tahun 2011 tentang pengesahan CRPD (Convention on the right of person with disability) yaitu pembangunan kota harus ramah terhadap hak asasi manusia atau kebutuhan difabel, pemenuhan hakhak difabel yang dimaksud antara lain 
hak inklusi, hak aksesibilitas berupa bangunan fisik, transportasi dan universal design, hak bermobilitas, hak untuk bekerja, sekolah dan kesehatan serta hak untuk memanfaatkan waktu luang dan rekreasi sampai dengan kondisi darurat dan bencana alam.

Masyarakat berkebutuhan khusus merupakan masyarakat yang mempunyai keterbatasan tertentu dan mempunyai kesempatan yang sama dalam melakukan aktivitas. Menurut John Maxwell (1995) difabel atau masyarakat berkebutuhan khusus dibagi atas beberapa jenis yaitu difabel tunanetra, tunadaksa, tunarungu, tunawicara dan tunagrahita. Kecacatan yang sangat memiliki sifat ketergantungan adalah tunanetra dan tunadaksa. Kedua kecacatan ini mengakibatkan kesulitan dalam melakukan mobilitas secara mandiri di bandingkan dengan jenis kecacatan yang lainnya. Kesulitan ini diakibatkan karena ketidaksempurnaan penglihatan dan organ tubuh seperti kecacatan pada kaki dan anggota tubuh lainnya (Aqila,2012).

Salah satu kota yang memiliki jumlah difabel terbanyak adalah Kota Surakarta yaitu sebanyak 1.474 orang, karena Kota Surakarta merupakan salah satu pusat rehabilitasi difabel di Indonesia (Dinsos,2015).

Selain menjadi pusat rehabilitasi Kota Surakarta juga merupakan salah satu kota di Indonesia yang telah dijuluki sebagai kota ramah difabel atau surganya para difabel. Julukan ini didukung dengan penghargaan penghargaan yang didapatkan (Wordpres, 2017).

Penghargaan yang didapatkan merupakan cermin kota ramah difabel yang sebenarnya dalam pelayanan sosial maupun infrastrukturnya.

Jika membayangkan kota ramah difabel berarti kota tersebut telah menyediakan semua kebutuhan difabel sesuai standar pelayanan, baik itu transportasi umum, pendidikan, kesehatan, pekerjaan, rehabilitasi dan kebutuhan sosial lainnya tanpa terkecuali. Oleh karena itu dilakukan penelitian terkait "kesesuaian
pemenuhan kebutuhan difabel
tunanetra dan tunadaksa di Kota
Surakarta terhadap kriteria kota ramah difabel" untuk melihat seberapa besar tingkat kesesuaian pencapaian Kota Surakarta sebagai kota ramah difabel khususnya difabel tunanetra dan tunadaksa.

\section{TINJAUAN PUSTAKA \\ 2.1. Difabel/Masyarakat Berkebutuhan Khusus}

John Maxwell (1995) difabel adalah orang yang memiliki kelainan fisik atau mental yang dapat mengganggu atau sebagai rintangan baginya dalam melakukan aktivitas.

Menurut Undang - Undang No 4 Tahun 1997 tentang penyandang Cacat mendefinisikan difabel sebagai difabel adalah orang yang mempunyai kelainan fisik atau mental yang terdiri dari (a) penyandang cacat fisik, (b) penyandang cacat mental dan (c) penyandang cacat fisik dan mental.

Sedangkan Demartoto (2007) mengklasifikasikan tiga jenis kecacatan sebagai berikut : (a) cacat fisik seperti gangguan penglihatan atau tuna netra, tuna rungu , tuna wicara dan tuna daksa, (b) cacat mental seperti gangguan tingkah laku yang disebut dengan tuna grahita dan (c) Cacat fisik dan mental adalah keadaan yang menyandang dua jenis kecacatan sekaligus.

\subsection{Kriteria Kota Ramah Difabel}

Hak -hak difabel tersebut diatur dalam undang-undang masing-masing negara ataupun masing - masing daerah. Ada 3 undang-undang di Indonesia yang bisa digunakan sebagai acuan untuk pembangunan kota ramah difabel yaitu CRPD (Convention on the Rights of Persons with Disabilities), UU RI No 4 Tahun 1997 Tentang Penyandang Cacat, UU RI No 19 Tahun 2011 Tentang Pengesahan CRPD dan Peraturan Daerah Kota Surakarta Nomor 2 Tahun 2008 tentang Kesetaraan Difabel.

Berdasarkan keempat peraturan dan perundang-undangan tersebut 
terdapat 6 hak difabel yang harus dibangun atau dicapai untuk mewujudkan kota ramah difabel yaitu: (1) Aksesibilitas atau universal design infrastruktur, fasilitas termasuk taman kota dan moda transportasi adalah aksesibilitas untuk semua orang: anakanak, ibu hamil, difabel dan manula, (2) Rehabilitas (3) Bantuan Sosial (4) Pendidikan (5) Peran serta pembangunan dan (6) Lapangan Pekerjaan. Berikut ini merupakan uraian keenam hak difabel yang harus dipenuhi beserta standarnya.

a. Aksesibilitas fisik terdiri dari aksesibilitas bangunan umum, aksesibilitas pertamanan dan pemakaman umum serta aksesibilitas pada transportasi umum.

b. Rehabilitasi terdiri atas rehabilitasi medis, rehabilitasi vokasional atau keterampilan serta rehabilitasi sosial.

c. Bantuan Sosial berkaitan segala macam bentuk bantuan sosial seperti pendidikan untuk difabel hingga bantuan alat untuk penyandang cacat.

d. Pendidikan berkaitan dengan pengadaan pendidikan khusus untuk difabel berupa SLB dan pendidikan inklusi.

e. Peran serta pembangunan berkaitan dengan hak difabel yang perlu diikutkan dalam kegiatan pembangunan minimal dalam proses perencanaan berlangsung.

f. Lapangan pekerjaan berkaitan dengan ketentuan daerah terkait perekrutan dan pemberian kesempatan terhadap difabel untuk bekerja yaitu BUMN, BUMD maupun swasta yang mempekerjakan sekurang-kurangnya 100 (seratus) orang harus mempekerjakan 1 (satu) sesuai dengan persyaratan, kualifikasi pekerjaan serta jenis kecacatan.

\section{METODE PENELITIAN}

Metode penelitian ini berisi ruang lingkup penelitian metode analisis yang digunakan, yaitu sebagai berikut :

\subsection{Ruang Lingkup}

Ruang lingkup wilayah penelitian ini adalah Kota Surakarta karena merupakan salah satu kota yang telah masuk nominasi kota ramah difabel dengan urutan 15 besar dari 115 negara. Ruang lingkup wilayah penelitian tersebut dapat dilihat pada Gambar 1. Sementara itu ruang lingkup pada penelitian ini menggunakan data pada saat penelitian ini berlangsung.

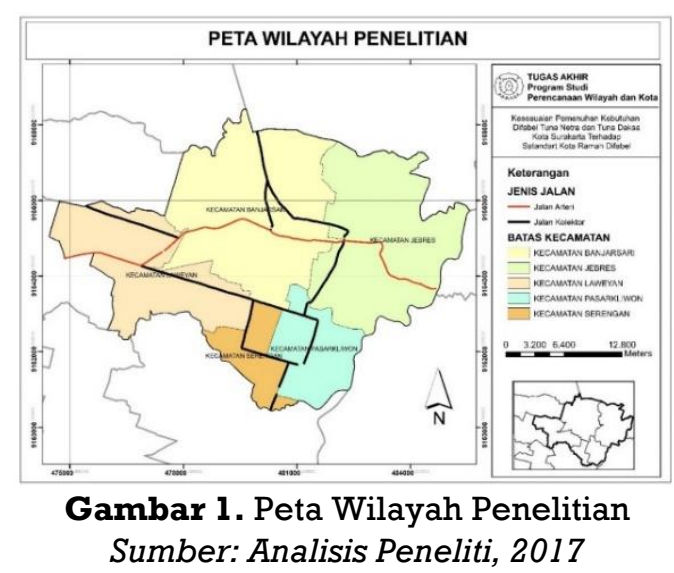

\subsection{Metode Analisis}

Pendekatan penelitian dalam mengukur kesesuaian pemenuhan kebutuhan tuna netra dan tuna daksa di Kota Surakarta terhadap kriteria kota ramah difabel ini menggunakan pendekatan deduktif. Dalam pendekatan deduktif, peneliti menggunakan teori di awal penelitian sebagai kerangka kerja untuk keseluruhan penelitian.

Jenis penelitian ini merupakan jenis kuantitatif. Jenis penelitian kuantitatif adalah metode penelitian yang berlandaskan pada filsafat positivisme, digunakan untuk meneliti pada populasi atau sampel tertentu, pengumpulan data menggunakan instrumen penelitian, analisis data bersifat kuantitatif/statistik, dengan tujuan untuk menguji hipotesis yang telah ditetapkan (Sugiyono, 2011).

Variabel yang digunakan dalam penelitian ini dapat dilihat pada Tabel 1 . berikut ini. 
Tabel 1. Variabel Penelitian

\begin{tabular}{|c|c|}
\hline Variabel & Sub Variabel \\
\hline \multirow{3}{*}{$\begin{array}{l}\text { Aksesibilitas } \\
\text { Transportasi }\end{array}$} & Akses Pedestrian \\
\hline & Akses Halte \\
\hline & $\begin{array}{l}\text { Akses Kendaraan } \\
\text { Umum }\end{array}$ \\
\hline \multirow[t]{3}{*}{ Rehabilitasi } & Rehabilitasi Medis \\
\hline & $\begin{array}{l}\text { Rehabilitasi } \\
\text { Vokasional }\end{array}$ \\
\hline & Rehabilitasi Sosial \\
\hline Bantuan Alat & - \\
\hline \multirow{2}{*}{ Pendidikan Formal } & Pendidikan Khusus \\
\hline & Pendidikan Inklusi \\
\hline $\begin{array}{l}\text { Peran serta } \\
\text { Pembangunan }\end{array}$ & - \\
\hline Lapangan Pekerjaan & - \\
\hline
\end{tabular}

Untuk mendapatkan data dilakukan melalui survey data primer dan survey data sekunder. Teknik pengumpulan data primer dilakukan dengan cara observasi lapangan, wawancara dan kuisioner untuk data peran serta pembangunan dan data lapangan pekerjaan. Sedangkan teknik pengumpulan data sekunder dilakukan studi dokumen mengenai jumlah halte dan bus BST, fasilitas rehabilitasi sekolah inklusi dan sekolah khusus, data rute trayek, serta program dan jumlah bantuan alat yang didistribusikan.

Sampel pada penelitian ini adalah difabel tuna netra dan tuna daksa dan tempat kerja atau tempat usaha, sedangkan populasi yang digunakan adalah jalan arteri dan kolektor, halte dan bus BST.

Tabel 2. Sampel dan Populasi Penelitian

\begin{tabular}{|c|c|}
\hline \multicolumn{2}{|l|}{ Sampel } \\
\hline Sasaran & Jumlah \\
\hline $\begin{array}{l}\text { Difabel tuna netra dan tuna } \\
\text { daksa }\end{array}$ & 82 \\
\hline Tempat kerja atau usaha & 82 \\
\hline \multicolumn{2}{|l|}{ Populasi } \\
\hline Sasaran & Jumlah \\
\hline Halte & 91 \\
\hline Jalan & 48 \\
\hline
\end{tabular}

Sumber : Peneliti, 2017

Teknik analisis yang digunakan dalam penelitian ini merupakan teknik analisis skoring. Teknik analisis skoring dilakukan dengan 2 (dua) tahapan yaitu:

a. Analisis skoring kesesuaian pemenuhan kebutuhan difabel tuna netra dan tuna daksa di Kota Surakarta sebagai kota ramah difabel yang dinilai berdasarkan tiap variabel dengan cara : menentukan nilai rerata parameter, menentukan klasifikasi kesesuaian parameter, menentukan skor kriteria, dan menentukan klasifikasi kesesuaian pada masing-masing kriteria. Penentuan skor pada penentuan kesesuaian parameter dan kriteria dibagi menjadi klasifikasi sesuai (3), kurang sesuai (2) dan tidak sesuai (1).

b. skoring analisis kesesuaian pemenuhan kebutuhan tuna netra dan tuna daksa terhadap kriteria kota ramah difabel. Dengan cara menghitung nilai interval kemudian dilakukan untuk mencari nilai kesesuaian.

\section{HASIL DAN PEIMBAHASAN}

Hasil penelitian diuraikan berdasarkan analisis. Berikut ini merupakan hasil analisis yang telah didapatkan.

Pada pembahasan ini akan dijabarkan gambaran kriteria kota ramah difabel di Kota Surakarta yang di identifikasikan berdasarkan masingmasing kriteria yaitu terdiri dari: aksesibilitas transportasi, rehabilitasi, bantuan alat, pendidikan formal, peran serta pembangunan dan lapangan pekerjaan.

Secara garis besar Kota Surakarta merupakan salah satu kota di Indonesia yang telah menjadi pusat rehabilitasi untuk difabel, salah satu difabel dengan jumlah terbanyak adalah difabel tuna netra dengan jumlah 394 orang dan tuna daksa 150 orang, berbagai macam sarana telah dibangun guna mendukung Kota Surakarta sebagai kota ramah difabel, sehingga untuk mengetahui tingkat kesesuaiannya maka dilakukan penilaian pada masing- masing kriteria yang telah ditentukan.

Berikut ini merupakan tabel penilaian pada masing- masing kriteria . 
Tabel 3. Analisis Kesesuaian Pemenuhan Kebutuhan Difabel Tuna Netra dan Tuna Daksa di Kota Surakarta sebagai Kota Ramah Difabel

\begin{tabular}{|c|c|c|c|c|c|c|}
\hline $\begin{array}{l}\text { Kriteria } \\
\text { Variabel }\end{array}$ & $\begin{array}{c}\text { Sub } \\
\text { Variabel }\end{array}$ & Parameter & $\begin{array}{l}\text { Klasifikasi } \\
\text { Kesesuaian }\end{array}$ & Skor & $\begin{array}{l}\text { Total } \\
\text { Skor }\end{array}$ & $\begin{array}{c}\text { Klasifikasi } \\
\text { Kesesuaian }\end{array}$ \\
\hline \multirow{6}{*}{$\begin{array}{l}\text { Aksesibilitas } \\
\text { Transportasi }\end{array}$} & \multirow{3}{*}{$\begin{array}{l}\text { Akses } \\
\text { Pedestrian }\end{array}$} & $\begin{array}{l}\text { Kemudahan dilalui kursi roda: } \\
\text { - Jalur Pusat Aktivitas tinggi : } 2,5 \\
\text { meter - } 3 \text { meter } \\
\text { - Jalur pedestrian pada jalur aktivitas } \\
\text { rendah : minimal } 1,5 \text { meter }\end{array}$ & Tidak Sesuai & 0.11 & \multirow{6}{*}{1.15} & \multirow{6}{*}{ Tidak Sesuai } \\
\hline & & $\begin{array}{l}\text { Jalur penunjuk arah untuk difabel: } \\
\text { setiap pedestrian terbangun harus } \\
\text { tersedianya ubin pengarah yang } \\
\text { berbentuk garis-garis dan ubin } \\
\text { peringatan jika didepan pedestrian } \\
\text { terdapat bahaya }\end{array}$ & Tidak Sesuai & 0.11 & & \\
\hline & & $\begin{array}{l}\text { Bebas Bahaya: bebas lubang, jeruji, } \\
\text { atau penghalang seperti pohon, tiang } \\
\text { dan benda lainnya di tengah } \\
\text { pedestrian atau di tengah ubin } \\
\text { pengarah untuk tuna netra. }\end{array}$ & Tidak Sesuai & 0.11 & & \\
\hline & \multirow[t]{2}{*}{ Akses Halte } & $\begin{array}{l}\text { Kemudahan: } \\
\text { - } \text { ramp untuk kursi roda } \\
\text { - } \text { space kosong untuk kursi roda } \\
\text { - } \text { ubin pengarah tuna netra } \\
\text { - } \quad \text { rute trayek dengan huruf braille atau } \\
\quad \text { bersuara }\end{array}$ & Tidak Sesuai & 0.16 & & \\
\hline & & $\begin{array}{l}\text { Keamanan: } \\
\text { - } \quad \text { ram tidak curam dan licin } \\
\text { - } \text { ubin tanda peringatan didepan pintu } \\
\text { - } \quad \text { pintu kendaraan dan pintu halte } \\
\quad \text { sejajar }\end{array}$ & Tidak Sesuai & 0.16 & & \\
\hline & $\begin{array}{l}\text { Akses } \\
\text { Kendaraan } \\
\text { Umum }\end{array}$ & $\begin{array}{l}\text { Aksesibilitas kendaraan umum diukur } \\
\text { dari : } \\
\text { - ketersediaan space khusus untuk } \\
\text { pengguna kursi roda } \\
\text { - pintu dapat dilalui kursi roda } \\
\text { - alat pegangan tangan untuk tuna } \\
\text { netra }\end{array}$ & Kurang Sesuai & 0.50 & & \\
\hline \multirow{3}{*}{ Rehabilitasi } & $\begin{array}{l}\text { Rehabilitasi } \\
\text { Medis }\end{array}$ & $\begin{array}{l}\text { Adanya pusat rehabilitasi (rumah sakit } \\
\text { dan rehabilitasi khusus) dengan } \\
\text { penanganan ahli madya ortopedi, } \\
\text { fisioterapi, occupational Therapy, } \\
\text { spesialis saraf dan spesialis mata. }\end{array}$ & Sesuai & 1.00 & \multirow{3}{*}{3.00} & \multirow{3}{*}{ Sesuai } \\
\hline & $\begin{array}{l}\text { Rehabilitasi } \\
\text { Vokasional }\end{array}$ & $\begin{array}{l}\text { - Tersedianya } 5 \text { ragam pelatihan } \\
\text { keterampilan untuk difabel } \\
\text { - Pelatihan diberikan kepada kedua } \\
\text { difabel } \\
\text { Adanya link kerja setelah pelatihan } \\
\text { keterampilan }\end{array}$ & Sesuai & 1.00 & & \\
\hline & $\begin{array}{l}\text { Rehabilitasi } \\
\text { Sosial }\end{array}$ & $\begin{array}{l}\text { Tersedianya panti sosial untuk Tuna } \\
\text { Netra dan Tuna Daksa }\end{array}$ & Sesuai & 1.00 & & \\
\hline Bantuan Alat & & $\begin{array}{l}\text { Bantuan alat berupa Tongkat, Kursi } \\
\text { roda dan alat bantu mobilitas lainnya } \\
\text { dari pemerintah setempat }\end{array}$ & Sesuai & 3.00 & 3.00 & Sesuai \\
\hline \multirow[t]{2}{*}{$\begin{array}{l}\text { Pendidikan } \\
\text { Formal }\end{array}$} & $\begin{array}{l}\text { Pendidikan } \\
\text { Khusus }\end{array}$ & $\begin{array}{l}\text { Terdapat masing-masing sekolah } \\
\text { sesuai jenjang pendidikan yaitu l SLB } \\
\text { tingkat SD, SMP dan SMA khusus tuna } \\
\text { daksa dan tuna netra. }\end{array}$ & Sesuai & 1.50 & \multirow{2}{*}{3.00} & \multirow{2}{*}{ Sesuai } \\
\hline & $\begin{array}{l}\text { Pendidikan } \\
\text { Inklusi }\end{array}$ & $\begin{array}{l}\text { - Kecamatan memiliki sekolah inklusi } \\
\text { tingkat SD dan SMP } \\
\text { - Kota menyediakan } 2 \text { jenis sekolah } \\
\text { menengah yaitu SMA dan SMK }\end{array}$ & Sesuai & 1.50 & & \\
\hline $\begin{array}{l}\text { Peran serta } \\
\text { Pembanguna } \\
\text { n }\end{array}$ & - & $\begin{array}{l}\text { Difabel dengan kategori sehat, aktif } \\
\text { dan tidak mengalami gangguan mental } \\
\text { dilibatkan dalam partisipatif } \\
\text { pembangunan : } \\
\text { - Diikutsertakan dalam penyusunan } \\
\text { rencana } \\
\text { - Kesempatan dalam mengemukakan } \\
\text { aspirasi } \\
\text { - Mendapat informasi terkait } \\
\text { pembangunan desa dari perangkat }\end{array}$ & Kurang Sesuai & 2.00 & 2.00 & Kurang Sesuai \\
\hline
\end{tabular}




\begin{tabular}{|c|c|c|c|c|c|c|}
\hline $\begin{array}{l}\text { Kriteria } \\
\text { Variabel }\end{array}$ & $\begin{array}{c}\text { Sub } \\
\text { Variabel }\end{array}$ & Parameter & $\begin{array}{c}\text { Klasifikasi } \\
\text { Kesesuaian }\end{array}$ & Skor & $\begin{array}{l}\text { Total } \\
\text { Skor }\end{array}$ & $\begin{array}{l}\text { Klasifikasi } \\
\text { Kesesuaian }\end{array}$ \\
\hline & & desa & & & & \\
\hline \multirow[b]{2}{*}{$\begin{array}{l}\text { Lapangan } \\
\text { Pekerjaan }\end{array}$} & \multirow[b]{2}{*}{ - } & $\begin{array}{l}\text { Penyandang cacat memiliki kesamaan } \\
\text { hak dan kesempatan untuk } \\
\text { mendapatkan pekerjaan sesuai } \\
\text { kemampuan }\end{array}$ & Tidak Sesuai & 0.50 & \multirow[b]{2}{*}{1.00} & \multirow[b]{2}{*}{ Tidak Sesuai } \\
\hline & & $\begin{array}{l}\text { Melarang diskriminasi atas dasar } \\
\text { kecacatan diukur dengan: } \\
\text {-keberlanjutan pekerjaan } \\
\text {-pengembangan karir/promosi jabatan } \\
\text { - Penggajian yang sama }\end{array}$ & Tidak Sesuai & 0.50 & & \\
\hline
\end{tabular}

Sumber: Analisis Peneliti, 2017

Pada akhir pembahasan identifikasi kesesuaian pemenuhan kebutuhan difabel tuna netra dan tuna daksa terhadap masing - masing kriteria kota ramah difabel. Penentuan skor Penetuan skor parameter adalah berdasarkan banyaknya parameter dan sub variabel yang terdapat pada kriteria tersebut. Sedangkan penilaian klasifikasi kesesuaian kriteria didapatkan berdasarkan interval kesesuaian yaitu sesuai (3.00 - 2.33), kurang sesuai (2.32 - 1.66) dan tidak sesuai (1.65-1.00).

Berdasarkan analisis kesesuaian kriteria Kota ramah difabel maka di dapatkan data terkait skor untuk mengetahui nilai kesesuaian secara keseluruhan. Perhitungan untuk menentukan nilai kesesuaian adalah sebagai berikut :

Interval $=\frac{\text { Nilai } \text { max }- \text { Nilai } \text { min }}{\text { Jumlah } \text { kelas }}=\frac{18-6}{3}=4$ Sesuai : jika nilai $14,01-18$

Kurang Sesuai : jika nilai 10,01 - 14

Tidak Sesuai : jika nilai 6-10

\section{Keterangan :}

- Jika hasil skoring memiliki nilai di antara 14,01 - 18, maka nilai tersebut masuk pada kategori sesuai

- Jika hasil skoring memiliki nilai di antara 10,01 - 14, maka nilai tersebut masuk pada kategori kurang sesuai

- Jika hasil skoring memiliki nilai di antara 6 - 10, maka nilai tersebut masuk pada kategori tidak Sesuai.
Tabel 4. Analisis Kesesuaian Pemenuhan Kebutuhan Tuna Netra dan Tuna Daksa Terhadap Kriteria Kota Ramah Difabel.

\begin{tabular}{|c|l|c|c|}
\hline No & \multicolumn{1}{|c|}{ Variabel } & $\begin{array}{c}\text { Hasil } \\
\text { Skor }\end{array}$ & Kategori \\
\hline 1 & $\begin{array}{l}\text { Aksesibilitas } \\
\text { Transportasi }\end{array}$ & 1.26 & $\begin{array}{c}\text { Tidak } \\
\text { sesuai }\end{array}$ \\
\hline 2 & Rehabilitasi & 3.00 & Sesuai \\
\hline 3 & Bantuan Alat & 3.00 & Sesuai \\
\hline 4 & Pendidikan Formal & 3,00 & Sesuai \\
\hline 5 & $\begin{array}{l}\text { Peran serta } \\
\text { Pembangunan }\end{array}$ & 2.00 & $\begin{array}{c}\text { Kurang } \\
\text { Seseuai }\end{array}$ \\
\hline 6 & $\begin{array}{l}\text { Lapangan } \\
\text { Pekerjaan }\end{array}$ & 1.00 & $\begin{array}{c}\text { Tidak } \\
\text { Sesuai }\end{array}$ \\
\hline & Nilai & $\mathbf{1 3 . 2 6}$ & $\begin{array}{c}\text { Kurang } \\
\text { Sesuai }\end{array}$ \\
\hline
\end{tabular}

Sumber : Peneliti, 2017

Berdasarkan hasil analisis di dapatkan bahwa kota Kota Surakarta berada pada kategori "Kurang Sesuai" sebagai kota ramah difabel. Hal ini berarti masih belum terpenuhinya semua kebutuhan difabel tunanetra dan tunadaksa. Berikut ini merupakan penejelasan dari masing-masing kriteria:

a. Aksesibilitas Transportasi

Aksesibilitas transportasi umum berada pada kriteria "tidak sesuai" hal ini berarti Kota Surakarta belum memenuhi kebutuhan difabel di aspek transportasi. Berdasarkan hasil analisis diketahui masih minimnya pedestrain yang sesuai standar difabel, halte yang terbangun sebgaian besar masih menggunakan design untuk kebutuhan non difabel serta 50\% Bus BST khususnya koridor 2 masih belum memenuhi standar difabel. Kesesuaian aksesibilitas halte berguna untuk memenuhi kebutuhan transportasi yang aman dan nyaman, keterjangkauan tarif transportasi 
umum dan sebagai sarana edukasi penunjang rehabilitasi untuk melatih kemandirian menggunakan transportasi umum.

b. Rehabilitasi

Rehabilitasi difabel di Kota Surakarta termasuk dalam kategori "sesuai" hal ini berarti Kota surakarta telah memenuhi kebutuhan difabel dalam aspek rehabilitasi. Berdasarkan hasil analisis telah tersedianya 14 rumah sakit dengan masing-masing terdapat 6 jenis spesialis yang mampu melayani tunanetra dan tunadaksa, terdapat 20 ragam pelatihan vokasional untuk difabel serta tersedianya panti sosial yang melayani dan menampung difabel tunanetra dan tunadaksa. Adanya pemenuhan kebutuhan rehabilitasi berpengaruh baik terhadap difabel yaitu difabel yang tinggal di Kota Surakarta dapat dengan mudah mengakses rehabilitasi kesehatan, pelatihan ketrampilan serta rehabilitasi sosial, tanpa harus mengeluarkan modal besar pergi ke luar kota untuk mendapatkan rehabilitasi yang lengkap. Rehabilitasi ini dapat membuat difabel menjadi lebih bermanfaat, sehat, lebih percaya diri dan bisa aktif di lingkungan masyarakat tanpa merasa minder dengan keterbatasan yang di milkinya.

c. Bantuan Alat

Bantuan alat termasuk dalam klasifikasi "sesuai" hal ini menunjukan bahwa Kota Surakarta telah memenuhi kebutuhan alat sebagai penunjang mobilitas difabel. Berdasarkan hasil analisi, berbagai macam bantuan alat untuk difabel tuna netra dan tuna daksa dari pemerintah maupun swasta telah rutin diberikan tiap tahunnya secara gratis diberikan oleh para penyandang cacat yang ada di Kota surakarta. Yaitu setiap tahun kurang lebih ada 12 jenis alat bantu untuk difabel yang siap dibagikan secara gratis. Bantuan alat ini sanagat berfungsi untuk difabel yang kondisi tubuhnya tidak dapat dipulihkan melalui terapi medis. Bantuan alat akan memudahkan difabel dalam melakukan aktifitas secara mandiri. Alat yang didapatkan secara gratis ini juga sangat meringankan beban difabel yang memiliki keterbatasan ekonomi. Oleh karena itu untuk meningkatkan kegiatan sosial ini dipelukan pendataan jumlah difabel secara rutin agar kegiatan ini tetap berjalan tiap tahunnya.

d. Pendidikan Formal

Pendidikan Formal yang terdiri dari pendidikan khusus dan pendidikan inklusi di Kota Surakarta termasuk dalam klasifikasi "sesuai" hal ini berarti Kota Surakarta telah memenuhi kebutuhan difabel dalam aspek pendidikan. Berdasarkan analsis sekolah khusus atau SLB dan sekolah inklusi telah tersebar di setiap kecamatan yang ada di Kota Surakarta hal ini sangat membantu ABK untuk mendapatkan hak bersekolah layaknya anak normal lainnya. Terpenuhinya pendidikan difabel sangat bermanfaat untuk dirinya yaitu lebih percaya diri, tumbuh menjadi anak normal tanpa melihat keterbatasan, pendidikan yang di dapat bisa menjadi bekal untuk menuju ke jenjang perguruan tinggi dan lebih mudah bersaing di dunia pekerjaan.

e. Peran serta Pembangunan

Peran serta pembangun termasuk dalam klasifikasi "kurang sesuai" hal ini berarti hal difabel dalam mengemukakan aspirasi dan keikutsertaan dalam proses pembangunan belum di penuhi. Berdasarkan analisis $59 \%$ difabel belum dilabatkan dalam peranserta pembangunan. Dampak dari tidak keikutsertaan difabel dalam proses pembangunan akan berpengaruh terhadap pembangunan yang tidak aksesibel oleh difabel. Oleh karena itu perlu diberikan kesempatan kepada difabel dalam memberikan pendapat serta saran dalam musyawarah pembangunan. Karena salah satu keberhasilan pembangunan yang sesuai sebagai 
Kota Ramah difabel diperlukan adanya aspirasi dan pendapat dari masyarakat berkebutuhan khusus.

f. Lapangan Pekerjaan

Lapangan pekerjaan termasuk dalam kategori "tidak sesuai" hal ini berarti kebutuhan difabel dalam mendapatkan pekerjaan belum terpenuhi. Berdasarkan hasil analisis sebagian besar lapangan pekerjaan di Kota Surakarta belum menerima difabel untuk bekerja, hanya sebagian kecil tempat kerja yang menerima difabel, seperti tempat kerja yang berhubungan dengan kepengurusan difabel dan jasa keterampilan. Dengan demikian, untuk pemenuhan lapangan pekerjaan untuk difabel tidak sepenuhnya harus mengandalkan pemerintah saja, melainkan dibutuhkan adanya dukungan dari keluarga difabel serta semangat dari diri sendiri untuk menerapkan skill yang di dapatkan melalui bekerja secara mandiri atau wirausaha.

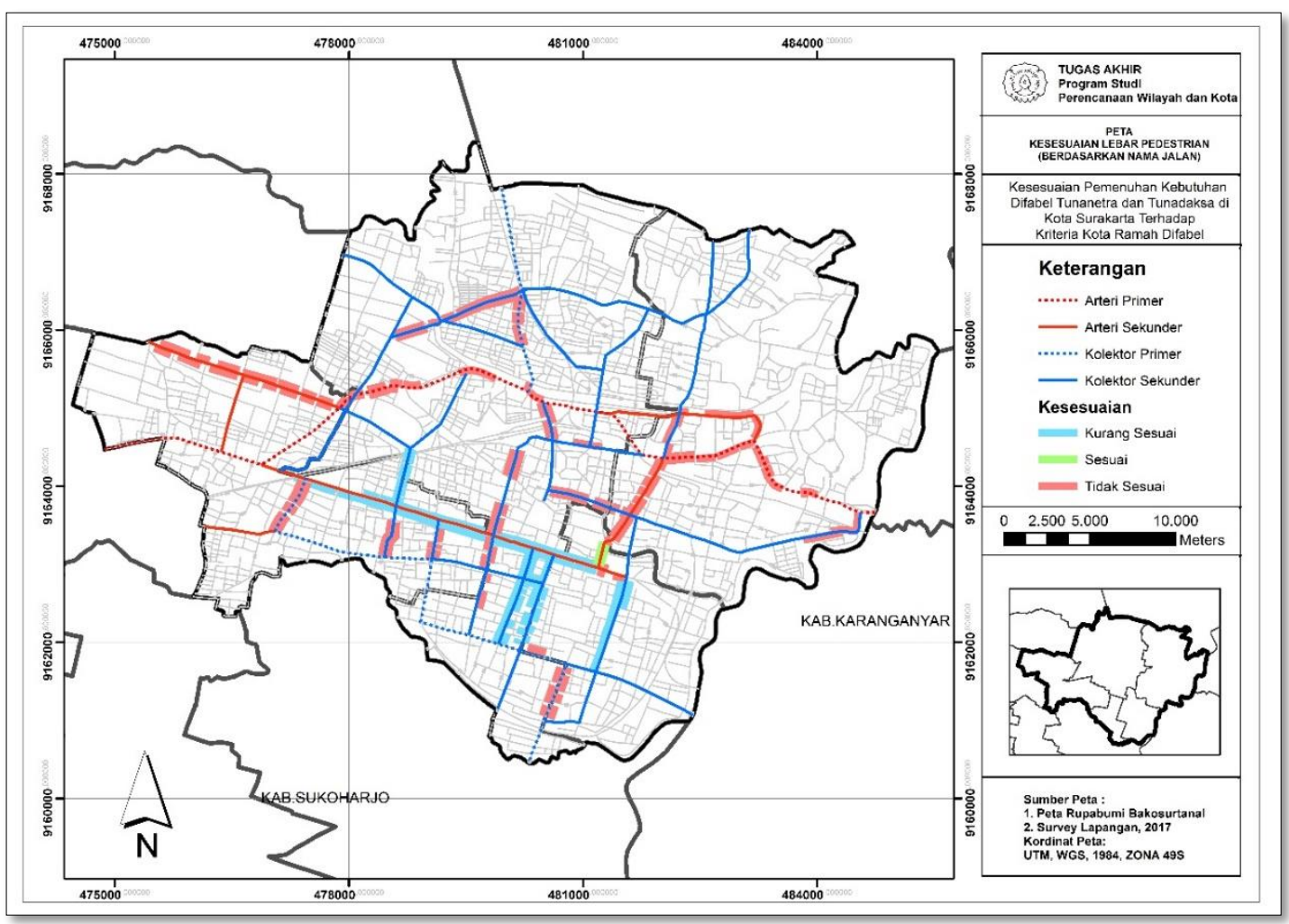

Gambar 1. Peta Kesesuaian Lebar Pedestrian yang Sesuai dengan Kebutuhan Difabel Sumber: Peta Rupabumi Bakosurtanal,Survey Lapangan, 2017 


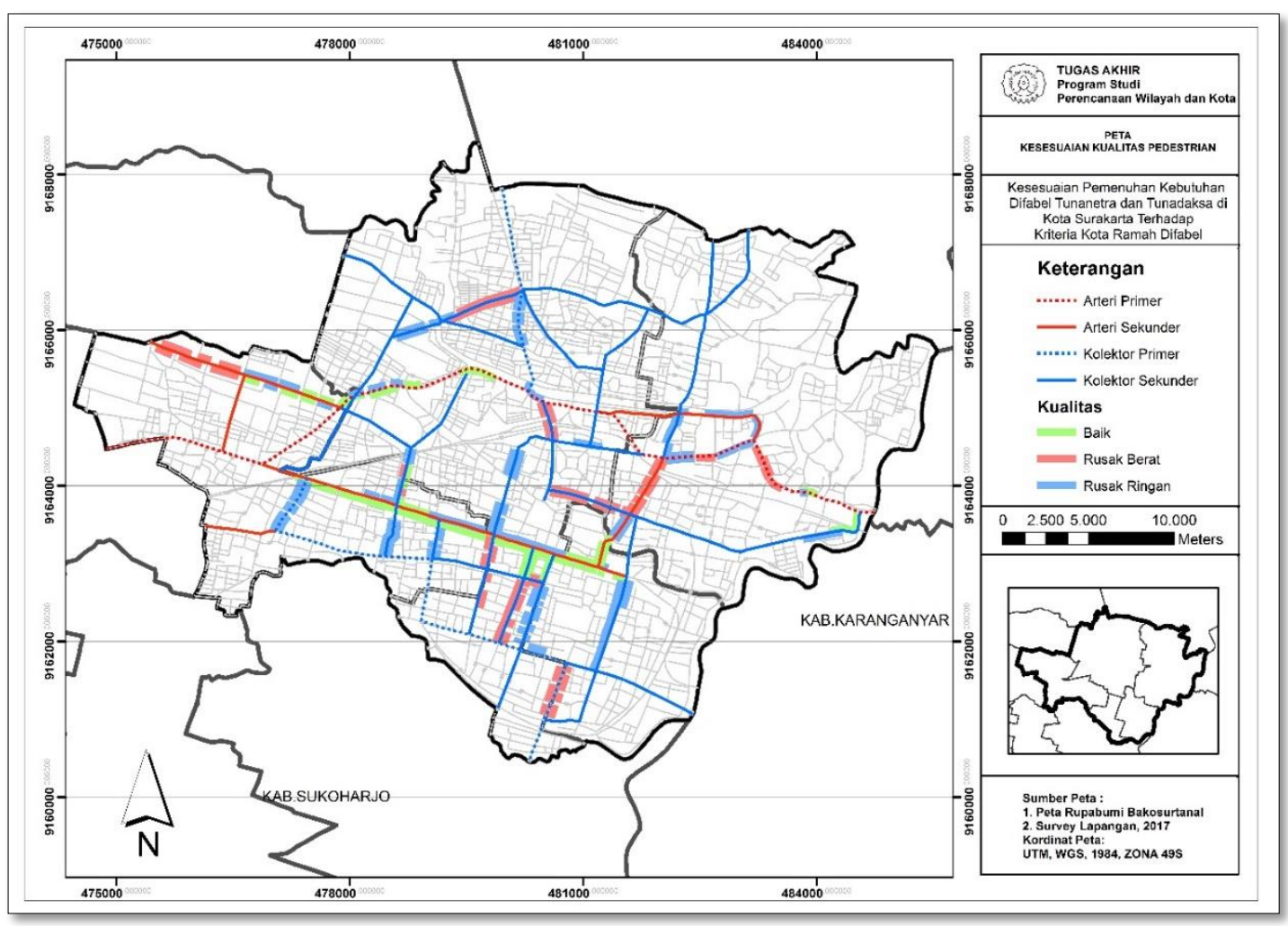

Gambar 2. Peta Kesesuaian Pedestrian Berdasarkan Kualitas Pedestrian Sumber: Peta Rupabumi Bakosurtanal,Survey Lapangan, 2017

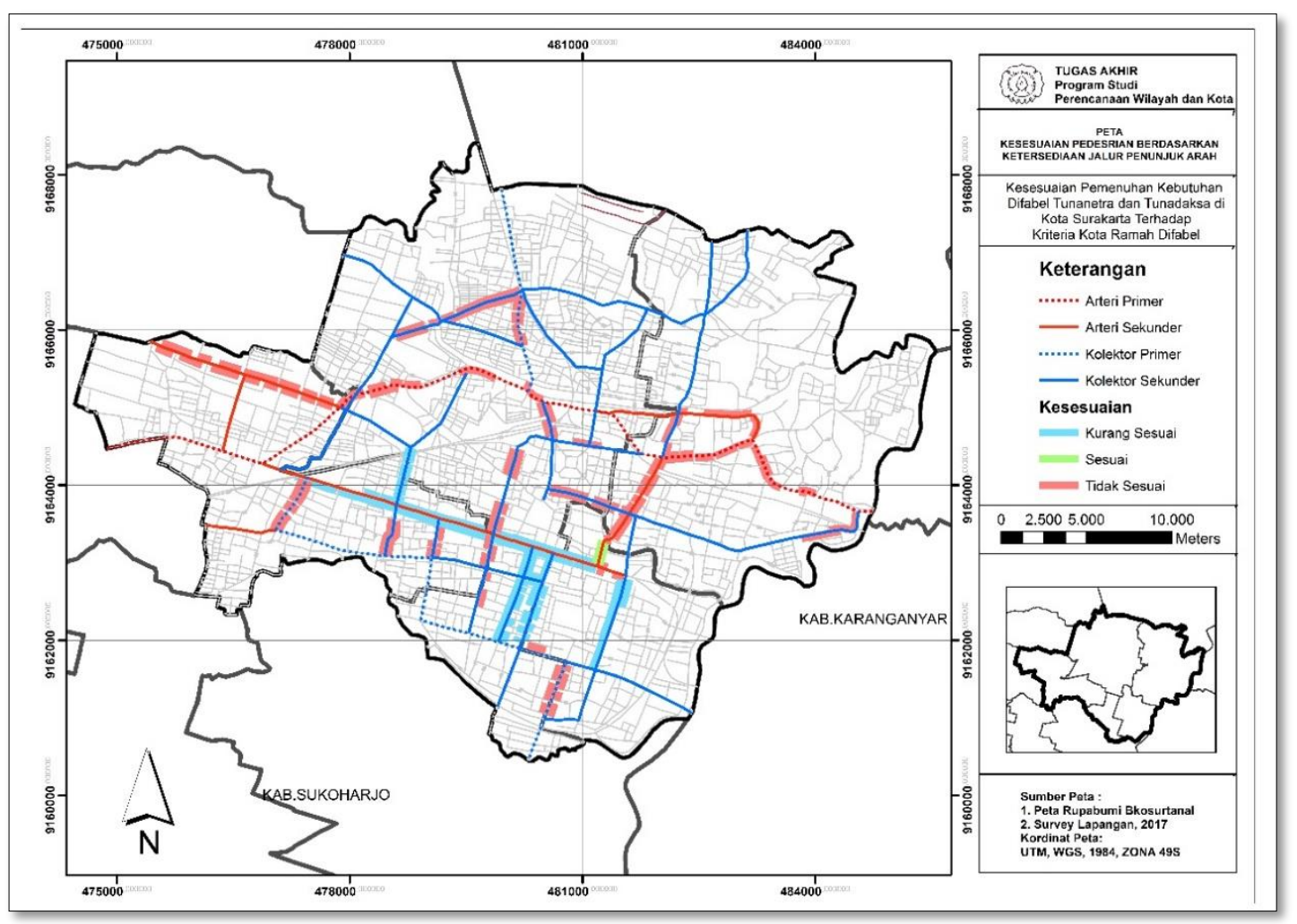

Gambar 3. Peta Kesesuaian Pedestrian Berdasarkan Jalur Penunjuk Arah Sumber: Peta Rupabumi Bakosurtanal,Survey Lapangan, 2017 


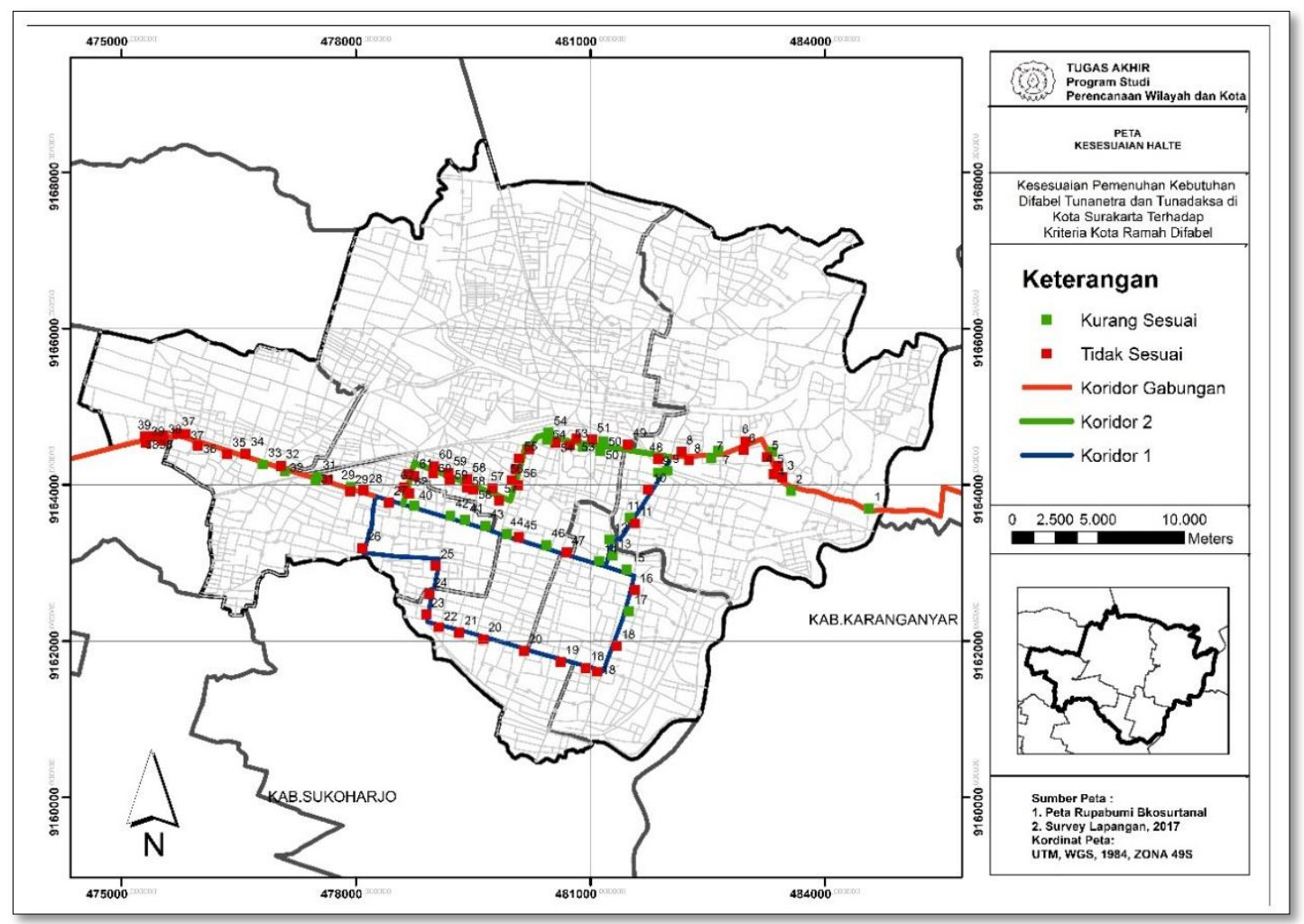

Gambar 4. Peta Kesesuaian Halte

Sumber: Peta Rupabumi Bakosurtanal,Survey Lapangan, 2017

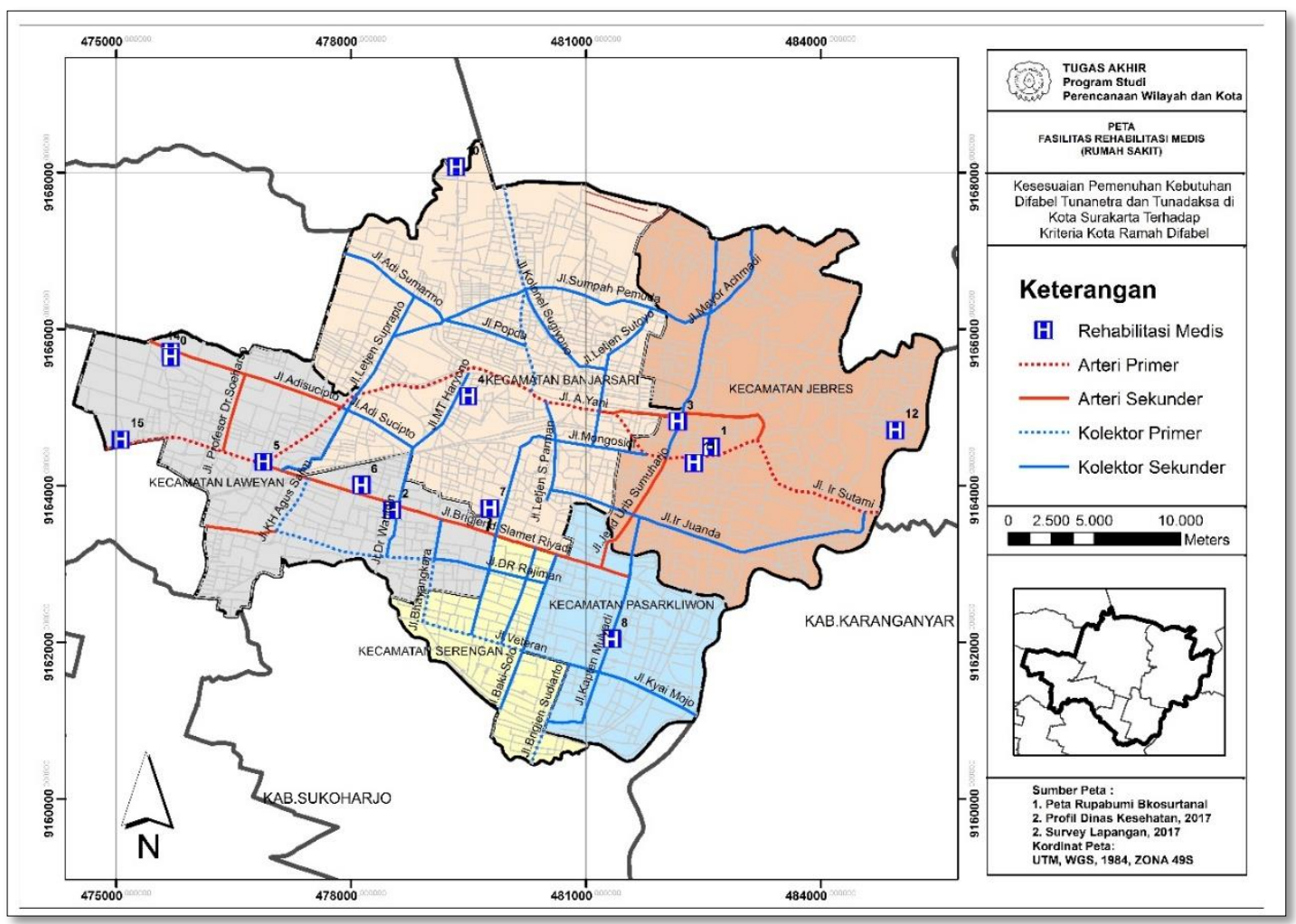

Gambar 5. Peta Sarana Rehabilitasi Medis

Sumber: Peta Rupabumi Bakosurtanal,Survey Lapangan, 2017 


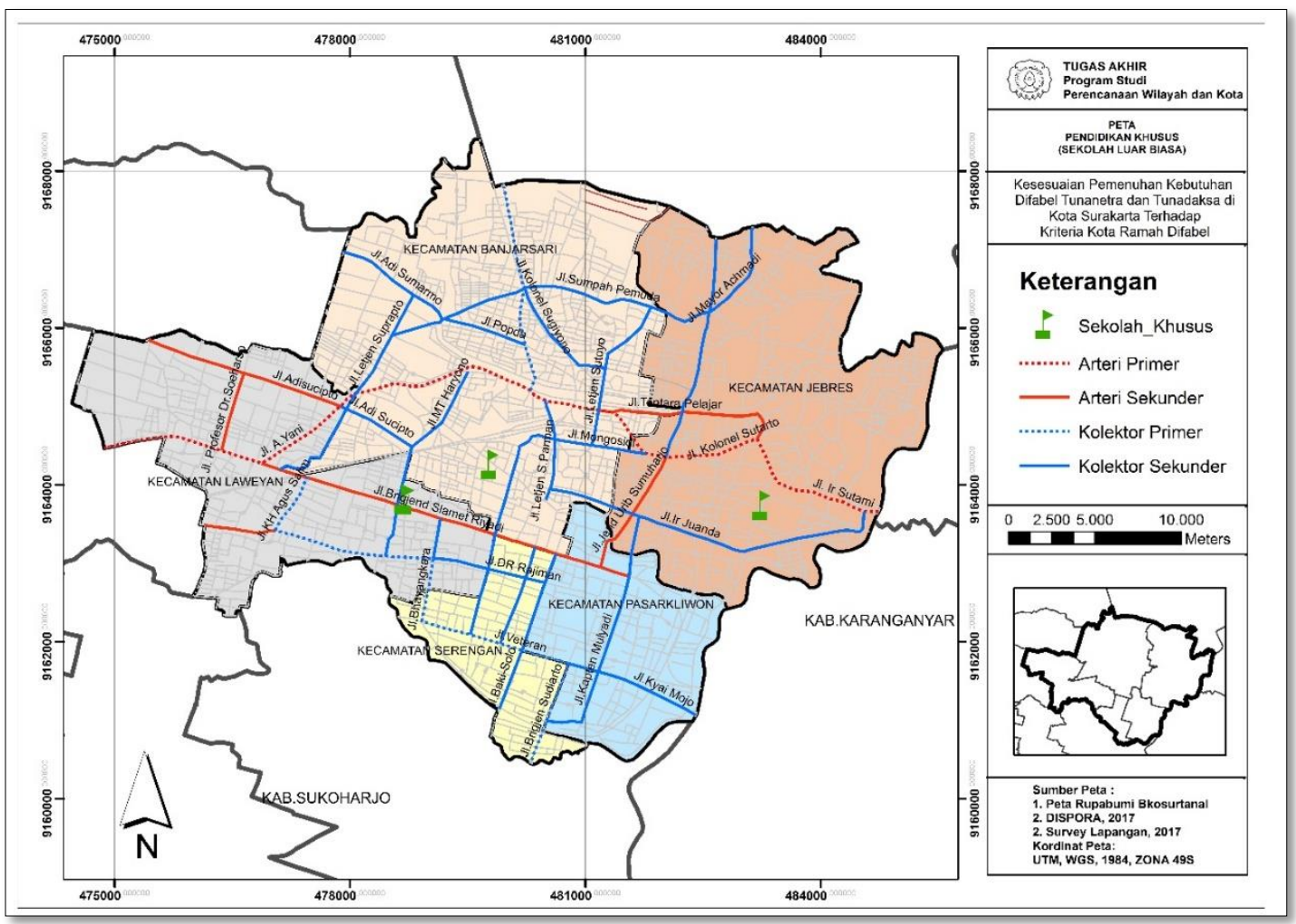

Gambar 6. Peta Sarana Pendidikan Khsus untuk Difabel Tunanetra dan Tunadaksa Sumber: Peta Rupabumi Bakosurtanal,Survey Lapangan, 2017

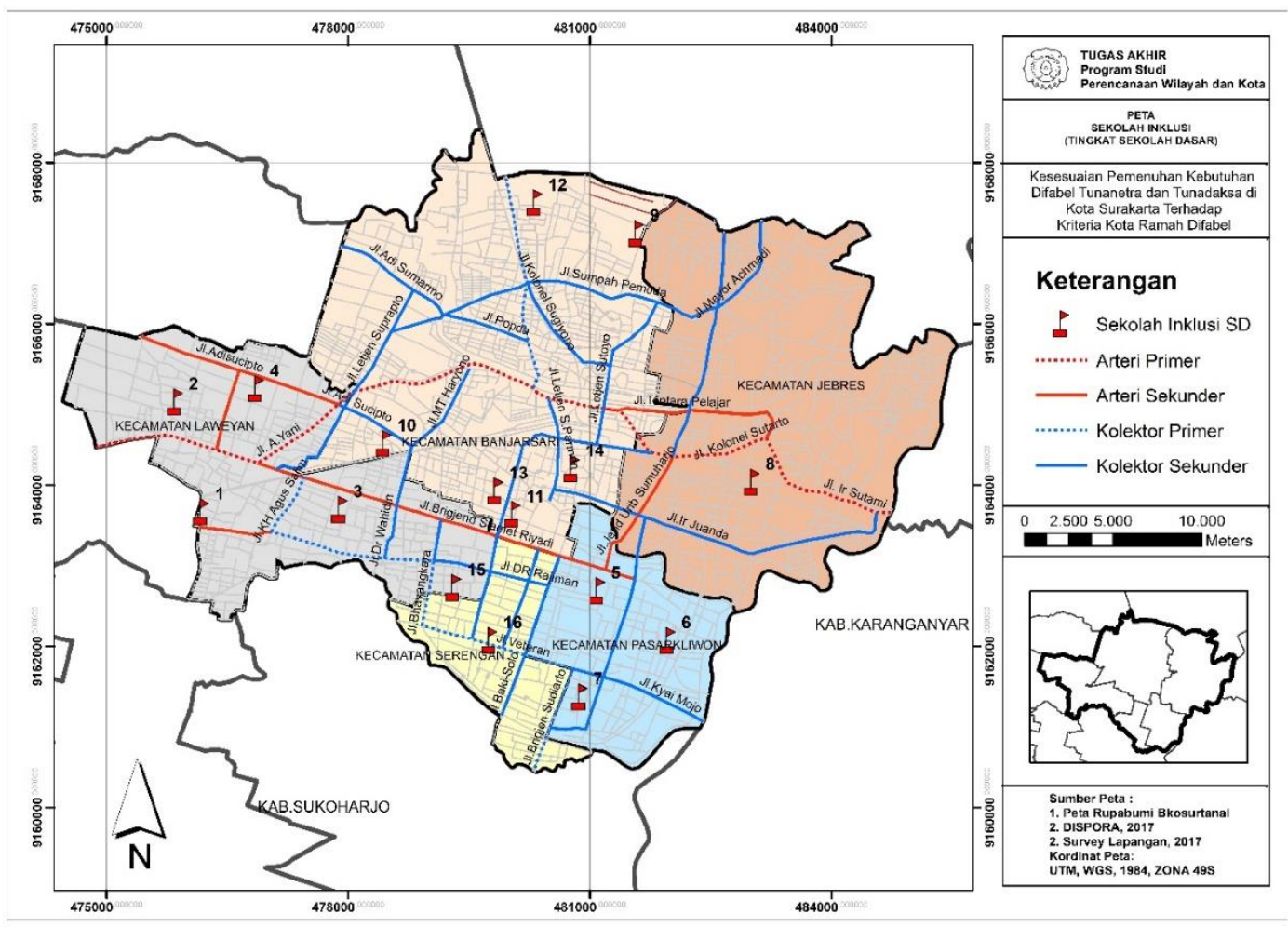

Gambar 7. Peta Sarana Pendidikan SD Inklusi

Sumber: Peta Rupabumi Bakosurtanal,Survey Lapangan, 2017 


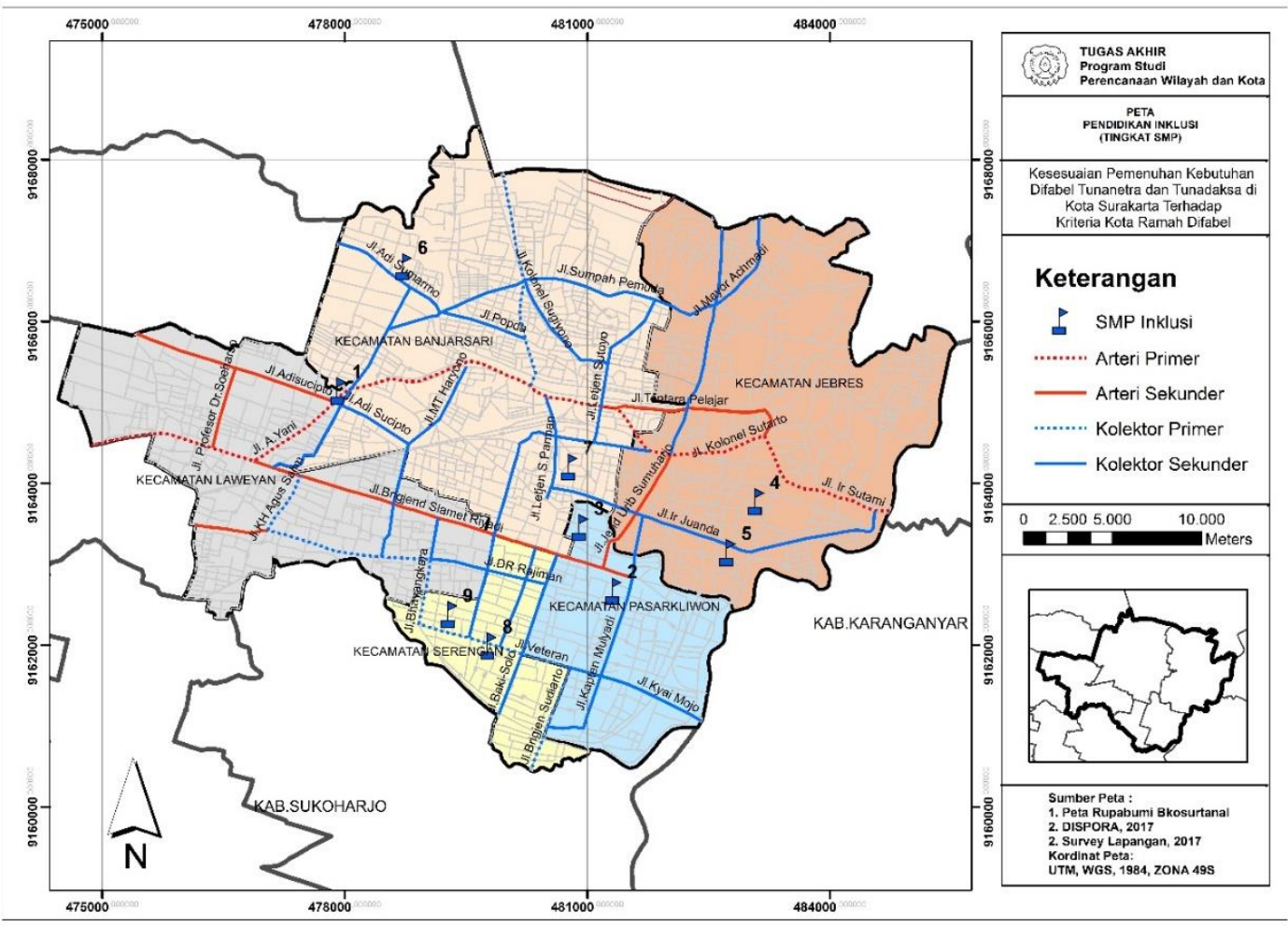

Gambar 8. Peta Sarana Pendidikan SMP Inklusi

Sumber: Peta Rupabumi Bakosurtanal,Survey Lapangan, 2017

\section{KESIMPULAN}

Dari hasil analisis, dapat disimpulkan bahwa kesesuaian pemenuhan kebutuhan difabel tuna netra dan tuna daksa di Kota Surakarta terhadap kriteria kota ramah difabel masuk dalam kategori kurang sesuai. Variabel tingkat kesesuaian yang mendapat nilai sesuai adalah variabel rehabilitasi bantuan alat dan pendidikan formal, variabel dengan nilai kurang sesuai adalah peran serta pembangunan dan variabel yang mendapat nilai tidak sesuai adalah aksesibilitas transportasi dan lapangan pekerjaan. Dari 6 kriteria hanya terdapat 3 kriteria yang telah sesuai.

Kategori kurang sesuai berarti Kota Surakarta belum memenuhi kebutuhan difabel tunanetra dan tuna daksa secara keseluruhan. Keenam kriteria tersebut saling berkaitan satu dengan yang lain yaitu, untuk mewujudkan aksesibilitas transportasi yang baik maka di butuhkannya keterlibatan difabel dalam peran serta difabel dalam mengikuti proses pembangunan, aspirasi difabel dapat mewakili kebutuhan akan transportasi yang lebih baik. Untuk mewujudkan difabel yang mandiri dalam memperoleh lapangan pekerjaan maka di butuhkan adanya pendidikan dan rehabilitasi yang sesuai dengan kebutuhannya sebagai jembatan untuk mendapatkan pekerjaan. begitupun dengan kemudahan bermobilitas difabel membutuhkan sarana rehabilitasi medis yang baik serta bantuan alat untuk menopang tubuhnya.

Enam kriteria kota ramah difabel tersebut perlu diwujudkan untuk membantu dan memudahkan difabel menjadi lebih mandiri dalam melakukan segala macam aktivitas, terjadinya kesetaraan perlakuan untuk difabel dan non difabel (dianggap sama), serta meningkatkan percaya diri untuk difabel dalam menghadapi perbedaan fisik yang dideritanya dari orang-orang di sekitarnya.

Oleh karena itu diperlukan kerjasama dari berbagai pihak untuk meningkatkan aspek-aspek yang belum sesuai untuk mewujudkan kota Surakarta sebagai Kota ramah difabel. 


\section{REFERENSI}

Aqila Smart, 2012. Anak Cacat Bukan Kiamat. Yogyakarta. Katahati.

Demartoto. 2007. Menyibak Sensifitas Gender dalam Keluarga Difabel. Surakarta: UNS Pers

Maxwell.J.C. 1995. Developing The Leaders Around You: How to Help Other Reach Their Full Potential. USA: Sae International, Inc.

Rinaldi Mirsa. 2011. Elemen Tata Ruang Kota.Yogyakarta:Graha Ilmu
Sugiyono. 2011. Metode Penelitian Kuantitatif, Kualitatif Dan R\&D. Bandung: Alfabeta

Surakarta Dalam Angka Tahun 2015

Undang - Undang Republik Indonesia Nomor 19 Tahun 2011 tentang Pengesahan CRPD

Undang - Undang Republik Indonesia Nomor 4 Tahun 1997 tentang Penyandang Cacat

Peraturan Daerah Kota Surakarta Nomor 2 Tahun 2008 tentang Kesetaraan Difabel. 